\title{
EXCESS PLUTONIUM DISPOSITION:
} THE DEEP BOREHOLE OPTION (U)

\section{AUGUST 9, 1994}

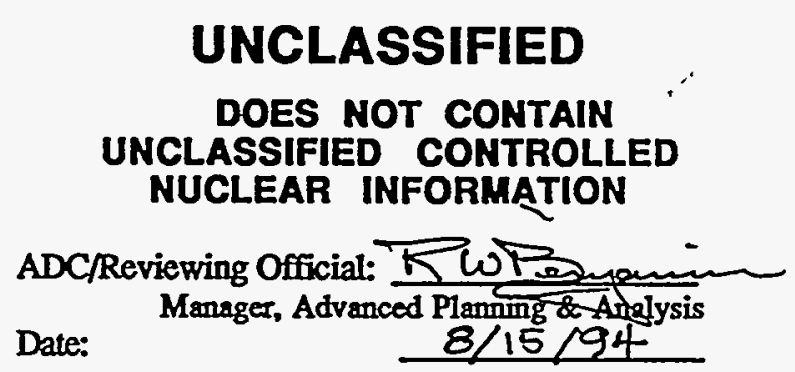

Westinghouse Savannah River Company Savannah River Site

Aiken, SC 29808 


\section{DISCLAIMER}

This report was prepared as an account of work sponsored by an agency of the United States Government. Neither the United States Government nor any agency thereof, nor any of their employees, makes any warranty, express or implied, or assumes any legal liability or responsibility for the accuracy, completeness, or usefulness of any information, apparatus, product, or process disclosed, or represents that its use would not infringe privately owned rights. Reference herein to any specific commercial product, process, or service by trade name, trademark, manufacturer, or otherwise does not necessarily constitute or imply its endorsement, recommendation, or favoring by the United States Government or any agency thereof. The views and opinions of authors expressed herein do not necessarily state or reflect those of the United States Government or any agency thereof.

This report has been reproduced directly from the best available copy.

Available to DOE and DOE contractors from the Office of Scientific and Technical Information, P.O. Box 62, Oak Ridge, TN 37831; prices available from (615) 576-8401.

Available to the public from the National Technical Information Service, U.S. Department of Commerce, 5285 Port Royal Road, Springfield, VA 22161. 


\section{DISCLAIMER}

Portions of this document may be illegible in electronic image products. Images are produced from the best available original document. 
WSRC-TR-94-0266

\title{
EXCESS PLUTONIUM DISPOSITION: THE DEEP BOREHOLE OPTION (U)
}

\author{
AUTHOR: \\ K. L. FERGUSON
}

APPROVED BY:

T. H. GOULD, MANAGER

STRATEGIC PLANNING \& ANALYSIS

WESTINGHOUSE SAVANNAH RIVER COMPANY

AUGUST 9, 1994

Westinghouse Savannah River Company Savannah River Site Aiken, SC 29808

PREPARED FOR THE U. S. DEPARTMENT OF ENERGY UNDER CONTRACT DE-AC09-89SR18035 
WSRC-TR-94-0266

THIS PAGE INTENTIONALLY LEFT · BLANK

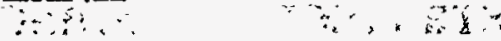

$\therefore \therefore \quad \therefore \times 2,0$ 


\section{CONTENTS}

Introduction

Background 1

Key Aspects of VDH Option..................................................................... 3

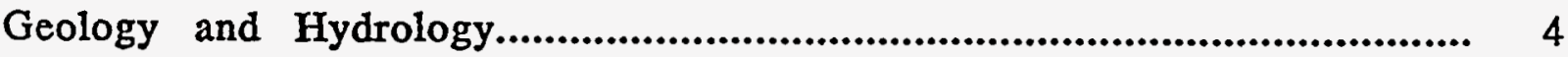

Design and Engineering ................................................................. 5

Safety and Licensing................................................................... 8

International Attention ...................................................................... 9

Conclusions............................................................................... 10

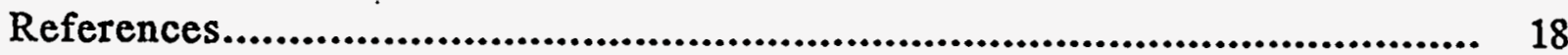




\section{LIST OF FIGURES}

\section{PAGE}

FIGURE 1 - Comparison of VDH and Repository Concepts ............................ 16

FIGURE 2 - Conceptual Layout of Emplacement Facility ................................. 17

LIST OF TABLES

PAGE

TABLE 1 - Underground Disposition Comparisons .................................... 12

TABLE 2 - Representative Work Structure and Status............................................. 13

TABLE 3 - Summary of Issues...................................................... 14 


\section{INTRODUCTION}

This report reviews the current status of technologies required for the disposition of plutonium in Very Deep Holes (VDH). It is in response to a recent National Academy of Sciences (NAS) report (Ref. 1) which addressed the management of excess weapons plutonium and recommended three approaches to the ultimate disposition of excess plutonium:

1. fabrication and use as a fuel in existing or modified reactors in a once-through cycle

2. vitrification with high-level radioactive waste for repository disposition

3. burial in deep boreholes

As indicated in the NAS report, substantial effort would be required to address the broad range of issues related to deep bore-hole emplacement.

Subjects reviewed in this report include geology and hydrology, design and engineering, safety and licensing, policy decisions that can impact the viability of the concept, and applicable international programs. Key technical areas that would require attention should decisions be made to further develop the boxehole emplacement option are identified.

\section{BACKGROUND}

The opportunity and support for arms reduction on an unprecedented scale has arisen with the end of the Soviet Union. The disposition of the fissionable materials from a possible dismantlement of tens of thousands of nuclear weapons has become a major related problem.

The NAS was requested by the National Security Adviser to do a full scale study. of the situation including the management and disposition of plutonium. The assignment was initiated during the Bush Administration with the mandate confirmed by the Clinton Administration.' The formal U.S. government sponsor is the Office of Nuclear Energy in the Department of Energy. A standing committee at NAS composed of scientists, engineers and policy experts carried out the assigument and published their recommendations as "Management and Disposition of Excess:Weapons Plutonium" (Ref. 1).

The NAS committee focused on the security risks posed throughout by the excess nuclear weapons and materials. The background information gathering by the team included visits to Russia where they met with major figures involved in formulating that country's policy on fissile materials disposition.

The recommendations of the NAS report include the identification of future focus, attention and development related to $\mathrm{Pu}$ disposition. Quantities in the range of 100 or more metric tons of plutonium from the United States and Russian nuclear weapons are cited by the report to be retired within the next decade. A prevailing theme in the NAS report is that the prime issue related to this material is security. Access to fissile material is considered by that team to be the primary barrier to a nuclear weapon(s) capability for those not yet in possession of it.

The NAS conclusions recommend the following options for long-term excess weapons plutonium disposition:

"The two most promising options are: Fabrication and use as a fuel, without reprocessing, in existing or modified nuclear reactors or vitrification in combination with high level waste." 
The report continues,

"A third option, burial of the excess plutonium in deep boreholes has until now been less thoroughly studied than have the first two options but could turn out to be comparatively attractive."

The recommendations of the report regarding these three approaches is that "A coordinated program of research and development to clarify and resolve the uncertainties" should be initiated.

There are significant differences between the properties of excess weapons grade plutonium and commercial spent nuclear fuel, including:

1. The volume of excess weapons $\mathrm{Pu}$ is correspondingly small.

2. The heat generation in plutonium is much less than in commercial spent fuel.

3. Proliferation and criticality risks with plutonium are much higher than with commercial spent fuel

These differences require consideration in view of the VDH concept and past assessments.

The information provided here is intended to provide further details on the borehole option, identify key uncertainties, and describe the potential advantages and match-up with security concerns.

Some technical studies which can provide information relevant to the VDH concept include:

1. An :active, German project ("KKTB") currently drilled to a depth of: more.

- Athan 7,000 meters deep combined with geological modeling and assessment.

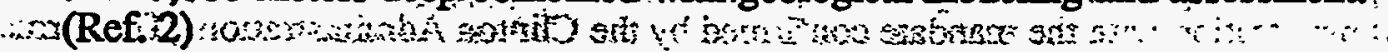

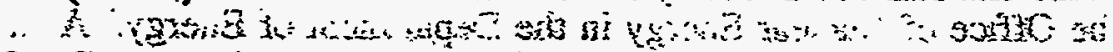

2. Comparative assessments leading to a (limited) commitment to the borehole concept in Germany but a:low rating in Sweden. (Ref.3,4 respectively)

3. Evolution by Sweden of a very robust fuel canister with expectation for a lifetime at repository depths of:"millions of years". (Ref. 5)

4. A German program planned to address issues of its borehole program for emplacement of high level waste to a maximum depth of 1400 meters. (Ref. G).

5. Continuing cooperative international efforts on safety assessment methodologies for underground disposition. (e.g., Ref. 7)

None of the studies, however, address directly the VDH concept which requires emplacing multitonned radioactive packages to a depth of more than 3000 meters. To date, the underground disposition evaluations and studies can be characterized as:

1. Emphasizing mined repositories not boreholes as the design concept.

2. Considering only disposition tunnels at depths in the range of 500 to 1,000 meters.

3. Focusing on high-level waste and/or spent commercial fuel for disposal. 


\section{KEY ASPECTS OF VDH OPTION}

The concept of deep borehole disposition of nuclear materials and/or high level waste is an extension of mined geologic repositories, but has its own set of advantages and challenges. The deep borehole concept has been referred to as "VDH" or "very deep hole" approach. The VDH proposed solution involves the emplacement of materials in shafts, relying on the extreme depth and the properties and integrity of surrounding rock for isolation. The depths envisioned for emplacement are thousands of meters deeper than repository designs.

Assurance that the boreholes are sufficiently deep requires confidence that radionuclides which may escape from the disposed canisters either will never reach the surface or usable aquifers, or will have decayed to innocuous levels by the time they do. This requires a combination of:

1. Very slow movement of ground water,

2. Very slow release of radionuclides to the ground water,

3. Retardation of radionuclide movement by chemical and/or physical interactions along flow paths, and

4. No impacts to natural characteristics or creation of significant new release paths due to operations related to the VDH disposition.

The VDH operations will include:

1. Drilling of deep boreholes.

2. Emplacing materials into approximately the bottom half of the boreholes

3. Inserting backfill material into approximately the top half of the boreholes

4. Closing of the shaft

The great depth, as deep as 5000 meters, permits less reliance on engineered barriers than required for repository disposal. Reliance on administrative controls or engineered barriers may be limited to the emplacement and shaft-enclosure stages if adequate site geologic and hydrologic stability could be demonstrated. Figure 1 provides a schematic of the concept.

Key steps leading to disposal of nuclear materials or waste by VDH include:

1. Assess geology and hydrology of potential sites

2. Develop techniques to model and analyze how the environment will affect the boreholes, how the borehole and contents will affect the geologic and hydrologic environment, and the transport of radionuclides

3. Establish the design and engineering effort related to drilling, emplacement and closure

4. Demonstrate compliance to relevant design, safety and regulatory requirements

5. Communicate interactively with the public and other stakeholders

6. Implement the VDH disposition approach for a specific site 
The deep borehole concept for disposition of excess weapons grade plutonium is viewed as a series of deep, vertical holes extending 4,000 or 5,000 meters into the earth, with nuclear material filling about half the depth covered with backfill to the surface. No direct experience exists with emplacement of packages to such depths. The packages would weigh tons or tens of tons. There are no current or planned facilities for spent fuel or waste emplacements at such depths. There are no projects in place or planned for drilling to such depths to address safety/control, retrievability, or material behaviors at extreme temperatures $\left(150^{\circ} \mathrm{C}\right.$ or greater) and pressures $(12,000 \mathrm{psi})$. Therefore, there have been no efforts to establish licensing requirements and design criteria for VDH disposal. As a consequence, developing a deep borehole option for excess weapons grade plutonium disposition would require a major initiative by DOE. The temperature and pressure increments of these depths will have a significant impact on design requirements and project feasibility. Table 1 provides a summary of the VDH and repository approaches to underground disposition.

The motivation for defining and evaluating the VDH concept is that this approach might offer unique and substantial security and safety benefits. It may provide the possibility of a virtually inaccessible end-state which relies on natural/physical, passive barriers for long term assurance of inaccessability.

\section{GEOLOGY AND HYDROLOGY.}

\section{Technology/Technical Status}

Several countries have initiatives in progress to characterize locations and to select prospective short lists of sites considered for disposition of commercial spent fuel and/or radioactive waste. Most projects are for repositories in the range of $1000 \mathrm{~m}$. deep. Móre robust data collection equipment technologies may be required for greater depths because of the higher temperature and

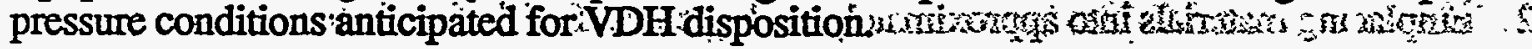

The current efforts at the "KTB" project in Germany have been briefly:summarized in thề litérature (Ref. 2) and the project provides a basis for experience at representative (currently $7000 \mathrm{~m}$.) depths. Laboratories exist elsewhere to address geology/hydrology issues; Canada (Ref. 8) and Belgium (Ref. 9). Facilities are being planned for France (Ref. 10) and Sweden (Ref. 11), but the current or planned emphasis at these facilities will 'probably reflect the repository orientation of the countries where they are located, i.e. depths of 500 to 1,000 meters.

Any proposed deployment of underground emplacement of materials will rely to a substantial degree on the current and predicted stability of that geosphere for proposed sites. Definition must be assigned to the "adequate level of stability required". Proven data accumulation techniques and technologies need to be deployed. Validated and verified analytic techniques will be needed to develop defensible conclusions related to a site's characterization and adequacy should a decision be made to proceed to develop the VDH option.

The performance adequacy of the VDH concept through the drilling, emplacement, closure and post-closure periods will require an integrated system of engineered, geologic and hydrologic barriers. The key to the definition of "adequate" geologic and hydrologic performance depends upon the extent of long-term reliance on the natural geosphere. There is a programmatic approach in which total reliance would be placed on geology and hydrology integrity at the time the borehole is closed. Other program philosophies proposed may require a very long term integrity of the engineered barriers, perhaps in excess of 10,000 years. 
Relevant site characteristics will include current migration paths for radionuclides, and ability to resist future formation changes or creation of routes tô the biosphere. Influences related to site conditions in the future would include: (i) natural events, (ii) borehole drilling and sealing activities, (iii) effects of the presence of nuclear material, and (iv) intrusion by humans. Representative factors that would enhance a site's attractiveness would include: (i) seismic stability, (ii) extremely slow ground water movement, and (iii) predicted chemical and/or physical retardation of radionuclides that could be released into the surrounding rock or soil.

Specific geological or hydrological parameters that will be important to performance assessments include, for example:

- Mechanical strength

- Permeability

- Porosity

- Salinity of ground water

- Thermal conductivity

- Heat capacity

- Temperatures
- Sorption coefficients

- Diffusivity

- Dispersivity

- Distribution coefficients

- Transmissivity

- Moisture content of rock

- Pressure

Variations of those characteristics as a function of depth, temperature, pressure and radiation environments must be appreciated and modeled with confidence. : There may be a need for substantial amounts of characterization information accumulated at a large range of subsurface depths for any future decision to develop the VDH concept.

A key consideration is the data accumulation and measurement instrumentation technology and $:$, reliability at the temperatures $\left(150^{\circ} \mathrm{C}\right)$ and pressure $(12,000 \mathrm{psi})$ associated with representative depths $(3,000$ to 5,000 meters).

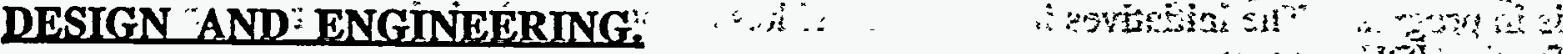

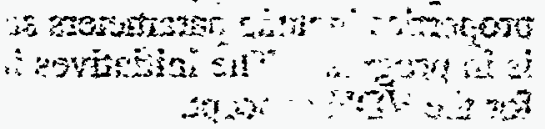

Technology/Technical Status:

(a) Drilling: Recent technology advances have resulted in an increasing confidence level of drilling success at the depths associated with the deep borehole emplacement coincept. Enhanced bit designs, creative use of drilling fluids, and increasing attention to pipe inspection have emerged recently. Increased attention to information gathering and assessment as well as creative schemes of modifying hole diameters are additional examples of how deep bore drilling is becoming more effective. The gas and oil exploration industry and companies are leaders in such technology advances. Potential issues of long term integrity of boreholes will need further attention especially if retrievability is a requirement.

(b) Fuel Canister: No design efforts are currently in progress to develop canisters having a requirement to withstand the temperatures and pressures of the emplacements associated with the VDH concept. A development which may be useful is the current design favored in the Swedish repository efforts (Ref. 5). The canister is a composite copper/steel design. The outer (copper) thickness of $50 \mathrm{~mm}$ is intended to provide corrosion protection. The inner (steel) thickness (also $50 \mathrm{~mm}$ ) is intended to provide mechanical strength. Other parameters of "KBS-3":

$\begin{array}{lll}\text { - } & \text { Height: } & 489 \mathrm{~cm} \\ \text { - } & \text { OD: } & 88 \mathrm{cms} \\ \text { - Weight } & 17 \text { tons (total) } \\ \text { Weight: } & 11 \text { tons (canister) }\end{array}$


The expected lifetime of this canister in the anticipated granite bedrock is "millions of years".

Because of the large margin inherent in the canister design, some of these features may be useful in the more extreme environments of the VDH option.

(c) Emplacement and Retrieval Equipment. Most of the effort in this design area has been documented by the Germans (Ref. 6). Handling tests with dummy canisters have taken place and mining authorities have approved a transport and handling system. Thirty test canisters and waste sources have been fabricated and await German licensing for more testing at the Asse mine. The testing will be performed in very shallow boreholes. In the Gorleben repository (under construction) the actual travel depth of emplacement will start $800 \mathrm{~m}$. underground and continue for approximately another $600 \mathrm{~m}$. Such information will be useful but not definitive for the VDH concept.

The borehole testing program planned by the Germans includes handling and emplacement demonstration as a key focus. There has recently been emphasis on an assessment of long-term dimensional changes ("convergence") of boreholes. This type of behavior can have significant emplacement and/or retrieval consequences. Recent measurements at temperatures well below expected extremes of the depths of deep borehole emplacement indicate a reduction in borehole diameter of one meter holes in the range of several millimeters after 1 year and further converging at a similar rate for the following year or two. At the more extreme pressures of the depths of the deep borehole concept the rates may be at an accelerated pace.

(d) Plugging and Backfill: Technical progress in this area has included material characterization studies in several countries. Programs are focused on materials that will be economicalin bulk quantities if they demonstrate sufficient functional performance. Characterization of key properties include parameters such as stress, strain, permeability, etc. Model validation work is in progress. The initiatives in place will address depths much shallower than envisioned for the VDH concept.

An example of efforts in progress include a CEC (Commission of European Communities) sponsored program in Belgium to evaluate clay as a backfill material (Ref. 12). Related testing will include radiation (CEREBUS), characterization under thermal loadings (CACTUS), and backfill procedures validation (BACCHUS project). Results have not yet been provided in the published literature.

The status and challenges for major technical developments include:

Drilling. Boreholes of the depths (3,000 to 5,000 meters) and diameters (in the range of a meter) have been accomplished, mostly by the oil and gas exploration industry. Currently (Ref. 13) there are dozens of boreholes in the U.S. in the range of 3,000 to 5,000 meters deep.

Technical advancements and improvements have addressed many of the problems for oil and gas drilling that arise at great depth, including the stability of the borehole itself. The integrity and behavior of the borehole needs to be given close attention because of impacts of directional stresses. Larger diameter drilling can be of special concern.

Advances to enhanced stability have included: (1) development of tools for analyzing stability,

(2) use of casings to support the hole, (3) close attention to selection of drilling fluids, and

(4) a process of step-down decreases in hole diameters for drilling to great depths. Improvements in drill bit design have also occurred regularly. 
Instabilities, if left unchecked, can result in elliptical rather than circular holes and/or substantial deviations from a truly vertical.hole. : These problems would tend to increase in severity as the hole depth increases, and can have obvious implications for the emplacement and retrieval phases of a VDH project. Recent technologies have demonstrated improvements in the ovality and verticality concerns, but not at conditions prototypic of VDH approaches.

Prediction of potential distuptions that the drilling process may have on the fracture characteristics of the penetrated geosphere have been improved. The "measurement-whiledrilling" technique has been developed for early identification of unexpected situations. The attention to failure analysis and inspections is indicative of an increased attention to drill piping integrity.

The most relevant deep borehole information may come from the German project ("KTB", Ref. 2) that has an objective of drilling to depths of more than 12,000 meters; and has already achieved 7000 meters. The project aim is to gather geological, geophysical and earth processes related information, and to perform detailed analyses of the data collected.

State of the art features of the "KTB" project include on site capability of 8 megawatts of power, modern data acquisition and processing, engineering advances in braking and drilling control systems, advanced pumping and circulation equipment, and instrumentation features that enable measurement-while-drilling. The drilling program includes five planned shifts of hole diameter with depth as well as changes in drilling fluids at certain depths. Piping inspection has been an important feature of the effort.

Total cost of a VDH project and operations is expected to be at least hundreds of millions of dollars. :Actual drilling costs would be in the range of tens of millions of dollars per borehole (Ref. 14). A small number of boreholes would be needed (e.g., one or two for a "tens of tons" inventory):

The new challenges that a VDH commitment for plutonium disposition would impose on drilling include:

1. Potential reliance on very long term canister integrity and access

2. Incremental heat loads on materials

3. Radiation loading on materials

4. Emplacement of heavy materials into such boreholes.

Fuel Canister and Emplacement. The sequence of steps for VDH operations includes on-site facilities and capabilities for receiving, handling, inspecting, temporarily storing, and preparing for transfer containers of plutonium for emplacement. Tasks will include design and operations related to remote handling, hot cells and shielding.

Past conceptual studies (Ref. 14) provide descriptions of the variety of tasks. Cask tranporters would carry containers (several per cask) of $\mathrm{Pu}$ from a central receiving facility to an emplacement facility. Rail vehicles would move the casks over the hole where the container modules are lowered. For time and economy, "strings" of several container/modules might be lowered at once. The procedure is repeated until an "emplacement zone" of the borehole (viewed as approximately the lower 50\% of the depth) is filled. After insertion of backfill material, the hole is plugged and the emplacement equipment is moved to the next hole. Figure 2 provides a conceptual layout. 
There is little precedent for using such deep holes for disposal of multi-tonned packages: The reliability of the series of hoistings, lowerings, inter-lockings and movement through thousands of feet would have to be demonstrated as part of a decision to further evaluate the VDH option. The potential safety and risk implications of related postulated events have yet to be fully addressed.

The emplacement depth and environment will impose design constraints on the canisters. For example, pressures may be in the range of $12,000 \mathrm{psi}$. Such a situation may have a major impact on container thickness as well as implying perhaps a very dense configuration of $\mathrm{Pu}$ and filler materials to add further assurance regarding crushing or compaction at great depths.

Specific details and the economic viability of the VDH concept are dependent upon the requirements for the canisters regarding retrievability and long-term integrity. VDH program objectives could mandate a long-term integrity canister (rather than long-term total reliance on the geosphere) should policy decisions mandate retrievable/intact containers (rather than "practicably irretrievable"). Such designs may become a limiting economic issue to the VDH effort (Ref. 14) due to retrieval design implications.

Plugging and Backfill. The backfilled volume resulting from the borehole drilling operation will become a major barrier between the plutonium and the environment. The open volumes between the canisters and casing would be filled with plugging materials. Representative plug materials include gravel, salt, clay, and cement grout. The material would be pumped into place or emplaced as blocks.

: The VDH approach can result in the need for a very tight sealant between the plutonium and immediate outside environment. Additional effort would be needed to assess the impact of $\therefore$ time, plututonium related heat loads, and radiation on the integrity of materials. Questions have also been raised regarding gas generation effects due to corrosion of container materials.: The impact of the external environment (temperature, pressure) would also need to be assessed. Such material behaviors could be critical if engineered barriers are required to be a key safety feature for very long time periods.

\section{SAFETY AND LICENSING. : . .}

Technology/Technical Status: Several international studies are in progress on the safety of underground disposition. Cooperative efforts on methodology development, safety analysis, and risk assessments are either planned or being implemented. The methodologies and the process of establishing event scenarios and sensitivity analysis may be of use to the VDH effort.

The DECOVALEX effort (Ref. 15) will be a multi-discipline/multinational effort managed by Sweden to address thermal-mechanical, geological-hydrological events. Mathematical models will be established and be validated. Participants include France, Canada, UK, Japan, Finland, and the U.S. Nuclear Regulatory Commission. The Lawrence Berkeley Lab has provided a Vice-Chairman. A further example of international cooperation involves the EVEREST (Ref. 16) program. Participants (France, Belgium, Netherlands, Germany) will work together to select scenarios for performing sensitivity studies. Some nations have sponsored safety analyses. 
The Gorleben site efforts in Germany offer the only current activity requiring licensing and involving extended borehole emplacements. Issues such as long term integrity, retrievability, material behaviors and related requirements, and monitoring are examples of significant considerations which may have little licensing precedent. The Gorleben site is under construction and has a target date of 2008 for operation, including emplacement of high level radioactive waste in boreholes of approximately 300 to 600 meters in length. The boreholes will be drilled starting at 800 meters below surface.

The borehole testing program planned by the Germans involves future attention to gas generation and release including generation of hydrogen through corrosion attack on potential canister materials. The testing program will include evaluating gases resultant from radioactive waste packages. Gas formation is also expected due to irradiation of surrounding salt rock and will be an additional focus of the testing program planned.

Performance assessments would involve conclusions related to: (i) a currently stable geosphere that will remain so, (ii) acceptably low probability of criticality, and (iii) no adverse radiological releases to the biosphere over an extremely long time frame of reference. Fundamental to such issues is the question of what is acceptable. Safety and licensing criteria have to be developed such that the level of necessary safety related performance for the borehole, canister, backfill, and geosphere be defined and against which a regulatory review can be performed.

Top level policy decisions will influence the direction of the regulatory and safety review. For example, the issue of retrievability might be a key parameter of interest from a security viewpoint. If "practicable irretrievability" is a requirement, the safety and design features of the canister, its duty cycle, and a tepresentative set of accidents to:analyze will be affected. Likewise, a more economical design can evolye if irretrievability implies that the canister must maintain its integrity only through: borehole closure. In such a case, long-term assurance of safety would rely on geology and hydrology: Such a situation would require extensive characterization of the site.

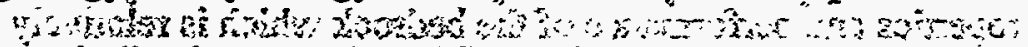

Past indications:are:that $U_{:} S$. regulatory agencies may have a problem with total reliance on the geosphere for safety assurance. With regards to the repository handling of high level waste, for example, the EPA has indicated a preference for an "assurance requirement" of several different barriers, both natural and engineered. This position reflects concern for sole reliance on geologic media. The uncertainties present in performance characteristics information is the issue.

\section{INTERNATIONAL ATTENTION.}

Over a dozen countries have been actively evaluating underground concepts for radioactive waste and/or spent commercial nuclear fuel inventories. IAEA conferences (Ref. 7) demonstrate focuses of interest, progress, current attentions and remaining issues. Some of the nations providing speakers at such meetings include:
- Germany
- Sweden
- Switzerland
- France
- United States

- Canada

- United Kingdom

- Belgium

- Italy

- Argentina
- Russia

- Japan

- Czechoslovakia

- Finland

- Spain 
Some of the areas of particular interest with current programs are:

- Geosphere modeling

- Site specific characterizations

- Behaviors of clay, granite, salt rock

- Pressure build up in rocks

- Safety analyses

- Heat and gamma radiation induced generation of gases

- Monitoring technologies

- Sealing materials behaviors

- Risk assessments

- Retrievable emplacement equipment and procedure demonstration

- Measurement of gas releases in sealed boreholes

- Thermal analysis

- Outgassing of natural gases at elevated temperatures from rock

- Gas migration through rock

Most of this work involves repository concepts with depths of 1000 meters or less. Although the information obtained will not constitute all that is needed for VDH purposes, some useful insight can be obtained from these efforts.

Sweden and Germany are examples of countries which have performed options assessments for different underground disposal alternatives for their commercial nuclear.programs. As a result of these activities, Germany has been focusing on a vertical borehole approach as the prime solution for heat producing radioactive waste. A borehole concept is also the back-up should hoisting technology render its plans. infeasible to use.heavy casks to dispose:spent fuel in theirepository: Sweden decided upon the mined repository concept as its solution for both fuel and waste 3 The vertical borehole option was given a lower ranking "mainly caused by the fact thất the safety of thè system is highly dependent on the properties and performance of the bedrock which is relatively unexplored to the proposed depths". There is some indication (Ref $r$ 19): of pressure to reopen the issue of the borehole emplacément optionin Swedens

\section{CONCLUSIONS}
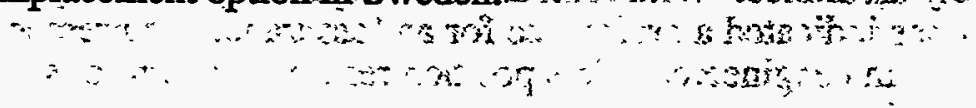

\section{Status Summary}

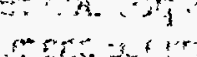

The Very Deep Hole option will have to confront numerous challenges to achieve success. Material compatibilities and the depths involved in disposing of volumes of plutonium raise important questions related to design and engineering involved with the drilling and containersias well as backfill and sealant materials. Policy questions, the regulatory review process; and effective mechanisms for communicating with the public would have to be addressed. Table-2 provides a list of some of the specific work packages that need to be accomplished should there be a decision to proceed with the VDH concept. Fundamental efforts, such as creation of site selection criteria and a framework for safety assessment and licensing related interactions would need to be established. Equipment may need to be developed to enable a reliable approach to collect important site information. No programs for fuel or waste emplacement exist which collect information and predict behaviors at the depths envisioned for the VDH alternative. A summary status of issues is provided in Table 3. 
The extreme depth of the boreholes and the resulting lengthy path to the biosphere may compensate for many of the challenges. Access and retrievability may be very difficult to attain for the deeply emplaced plutonium.... which may be the fundamental, significant advantage for this approach. A long term integrity requirement for containers could make the program infeasible...but that requirement may not be necessary if adequate levels of inaccessibility achieve the security objectives of excess weapons grade plutonium disposition.

No path forward will be quick or easy. The NAS report has concluded that for any option "it will be necessary to provide secure intermediate storage of surplus weapons plutonium for decades, since long-term disposition will take years to start and possibly decades to complete". Further evaluation of the VDH disposition approach may establish a true optional path forward. The concept is the most likely approach to achieve any inaccessibility objectives and/or assurance of safety and environmental acceptability by reliance in the long term on natural, physical barriers rather than engineered features.

There is ample precedent for sites within the DOE complex to support resolution of issues related to the deep borehole option. For example, pertinent technologies that are relevant and part of the existing core competencies at SRS include:

- Monitors and Sensors

- Seismic Technology

- Groundwater Mapping

- Risk Assessments

- Materials Behavior

- Container analysis and testing

Likewise, relevant SRS competencies that can be of programmatic value include:

- Safety Analysis Documentation

- Establishing of Design Criteria and Operational Performance Requirements

- Regulatory Interfacing

- Program Management

- Independent Design Review

- Site data base systems and documentation

This document has addressed current activities, relevant technology, gaps that exist, and areas for focusing evaluation efforts. Future performance assessments would need to address the VDH concept as a total system including the borehole and its depth, filler and sealant materials, canister, and the rock, soil, and groundwater environments. Overall acceptability will depend on the integrated response of that system when compared to specific security, safety and operational requirements that will need to be developed. Particular attention would need to be paid to the unique operating environments that would be involved. 
Table 1

Underground Disposition Comparisons

Repository

- 1000 meters or less below surface

- Mining technology: $\ldots, \cdots, \cdots$

- Many projects

- $50^{\circ} \mathrm{C}$ range of temperatures

- 3000 psi range of pressures
$\underline{\mathrm{VDH}}$

- As deep as 4,000 or 5,000 meters below surface

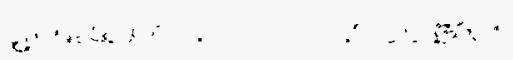

๑ Drillingโ"

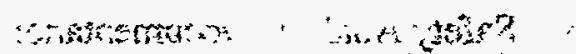

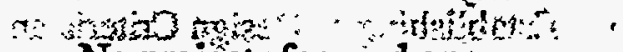

$\because \quad$ No projects focused on VDH at great depth

$\because 2 \therefore m$ $\therefore$ sints

- $150^{\circ}, \mathrm{C}$ range

- 12,000 psi range 
Table 2

Representative Work Structure for a VDH Program:

Status *

- Site Characterization and Investigations

- Design Criteria Development

- Canister Design(s)

- Site Selection Criteria Development

- Surface Facilities and auxiliary support systems

- Borehole Design(s) and Drilling Requirements

- Emplacement Facility and Equipment

- Safety and Environmental Analyses and Documentation

- Plugging Capability Design

- Monitoring and Surveillance

- Licensing Plan and Regulatory Interfacing

- Development Plans and Demonstration Facilities

- Análytical Model(s) Developmeñt

$\therefore$ Program Mánagementand Budget Develópment

- QA

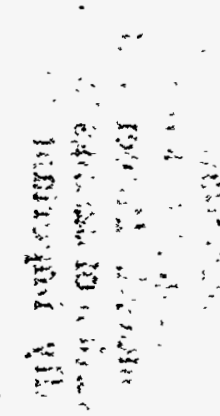

- Operational Readiness Reviews

(3)

(3)

- Communication Plan

- Waste Minimization Program

*

(1) Approach in place and/or current state of art can form basis of activity.

(2) Important information is in the planning process and may be a strong basis.

(3) Large effort needed, not currently planned or underway. 
Table 3

Summary of Underground Disposition of Spent Fuel/High Level Waste

\begin{tabular}{|c|c|c|}
\hline Topic & Current Situation & Representative Issues \\
\hline Drilling & $\begin{array}{l}\text { Depths representative of a deep } \\
\text { borehole project ( } 4000 \text { meters) have } \\
\text { been achieved. Proper drilling fluids } \\
\text { and insertion of casings for support are } \\
\text { especially important for deephole } \\
\text { drilling. }\end{array}$ & $\begin{array}{l}\text { Hole stability under increased heat and } \\
\text { radiation loadings and extreme pressure } \\
\text { conditions associated with VDH needs } \\
\text { to be established. Diameter of hole and } \\
\text { depth are key parameters. Stress/strain } \\
\text { impacts on surrounding geosphere will } \\
\text { be more critical than in previous drilling } \\
\text { precedents. }\end{array}$ \\
\hline $\begin{array}{l}\text { Geology - Hydrology, } \\
\text { Site Characterizations }\end{array}$ & $\begin{array}{l}\text { Salt and granite are among the } \\
\text { preferred candidates for "host rock". } \\
\text { Gathering of site specific information } \\
\text { is underway. Some groundwater } \\
\text { modeling has been initiated as well as } \\
\text { for dynamic response of rock. }\end{array}$ & $\begin{array}{l}\text { Most information will not be at the } \\
\text { greater depths characteristic of the VDH } \\
\text { concept. Models need to be further } \\
\text { validated. Enhanced data collection } \\
\text { technologies for VDH may need to be } \\
\text { developed. Swedish and French efforts } \\
\text { are underway for new laboratories to } \\
\text { perform geology/hydrology studies. }\end{array}$ \\
\hline Design and Engineering & $\begin{array}{l}\text { Designs for repository conditions are } \\
\text { being evolved. Fuel container materials } \\
\text { under consideration include copper, } \\
\text { titanium, stainless steel, nickel for } \\
\text { example. Swedish design in particular } \\
\text { is focused on long term integrity. } \\
\text { Clays, sands, grouts, salt being } \\
\text { evaluated as buffer or seal materials for } \\
\text { emplacement. }\end{array}$ & $\begin{array}{l}\text { Behaviors at VDH conditions would } \\
\text { have to be considered. Emplacement in } \\
\text { boreholes of extreme depths have yet to } \\
\text { be planned or demonstrated. Policies } \\
\text { on retrievability and life integrity of } \\
\text { container can have a major impact on } \\
\text { design features. Corrosion issues are } \\
\text { currently being studied related to } \\
\text { canisters. }\end{array}$ \\
\hline
\end{tabular}


Table 3

Summary of Underground Disposition of Spent Fuel/High Level Waste

Topic

Current Situation

Representative Issues

Safety and Licensing

Analyses have generally shown conformance regarding parameters such as predicted temperatires and radiation releases to the environment. Much international cooperation..

Control and safety related to emplacement remain to be verified, especially under VDH conditions. Development of licensing criteria for deep emplacements will need special attention. Analysis methodologies and appropriate combinations of inputs needs further validation. Gas propagation and release impacts will need further consideration.

Disposition Facility Projects

German project is most relevant (Gorleben site) target has been for 2008 initial operation. Gorleben will include high level waste emplacement in boreholes but no deeper than 1100 to 1400 meters." Canada, Germany, Sweden, USA, Finland have plans for spent fuels in repositories. Other nations have plans for wastes in repositories.

Sweden has recently decided that an operational demonstration project will be undertaken in order to establish better confidence in basic areas such as licensing, safety analysis, site characterization methodologies. Germans could emplace spent fuel in boreholes if repository hoisting technology for heavy casks 'cannot be demonstrated. 


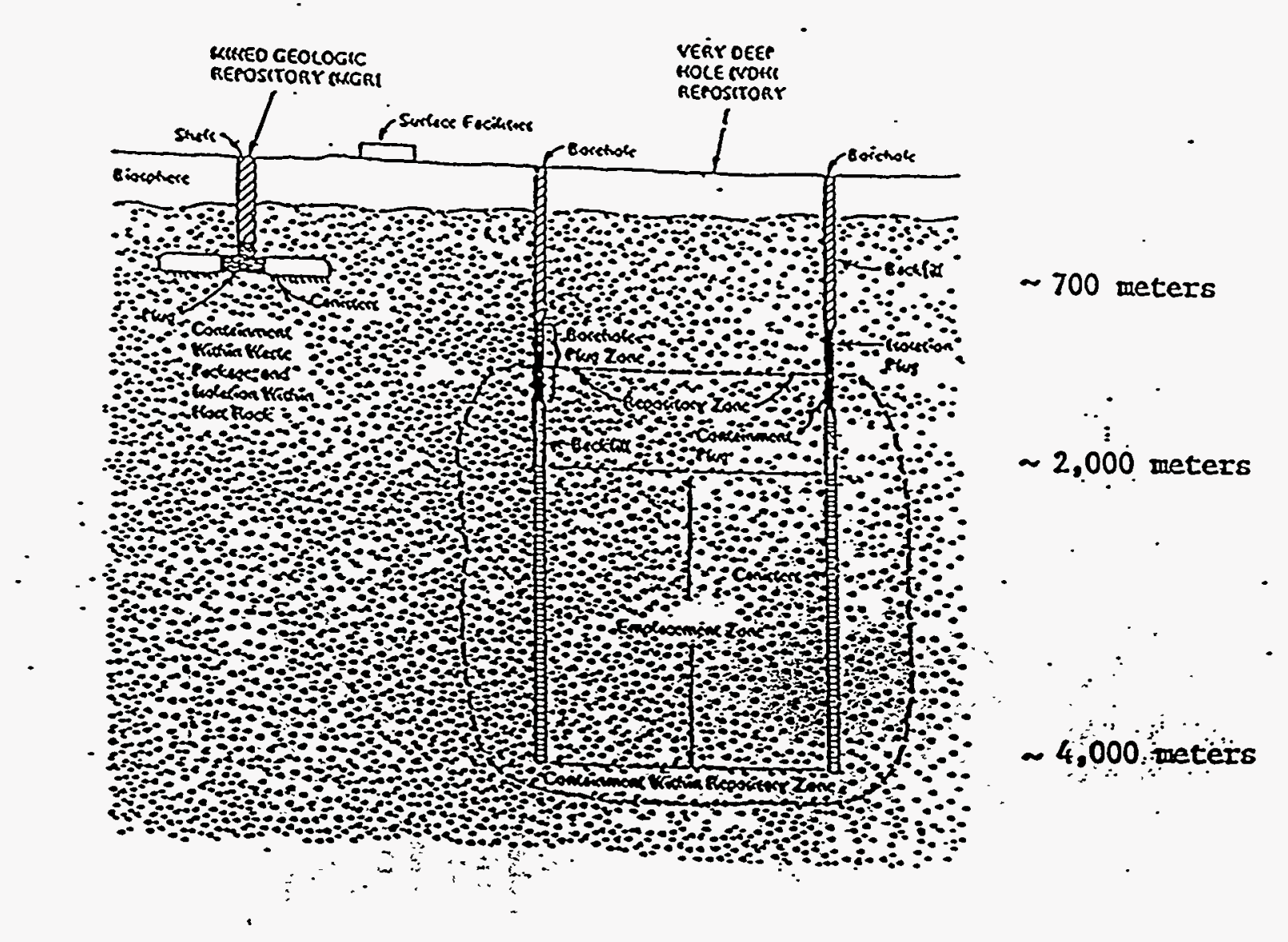

Figure 1 (redrawn from Ref. 14)

Comparison of VDH and Repository Concepts

Notes:

- Emplacement Zone: Depths in which Pu disposed

- Repository Zone: Geologic containment area, e.g. 1000 years of isolation in event of radionuclide release. 


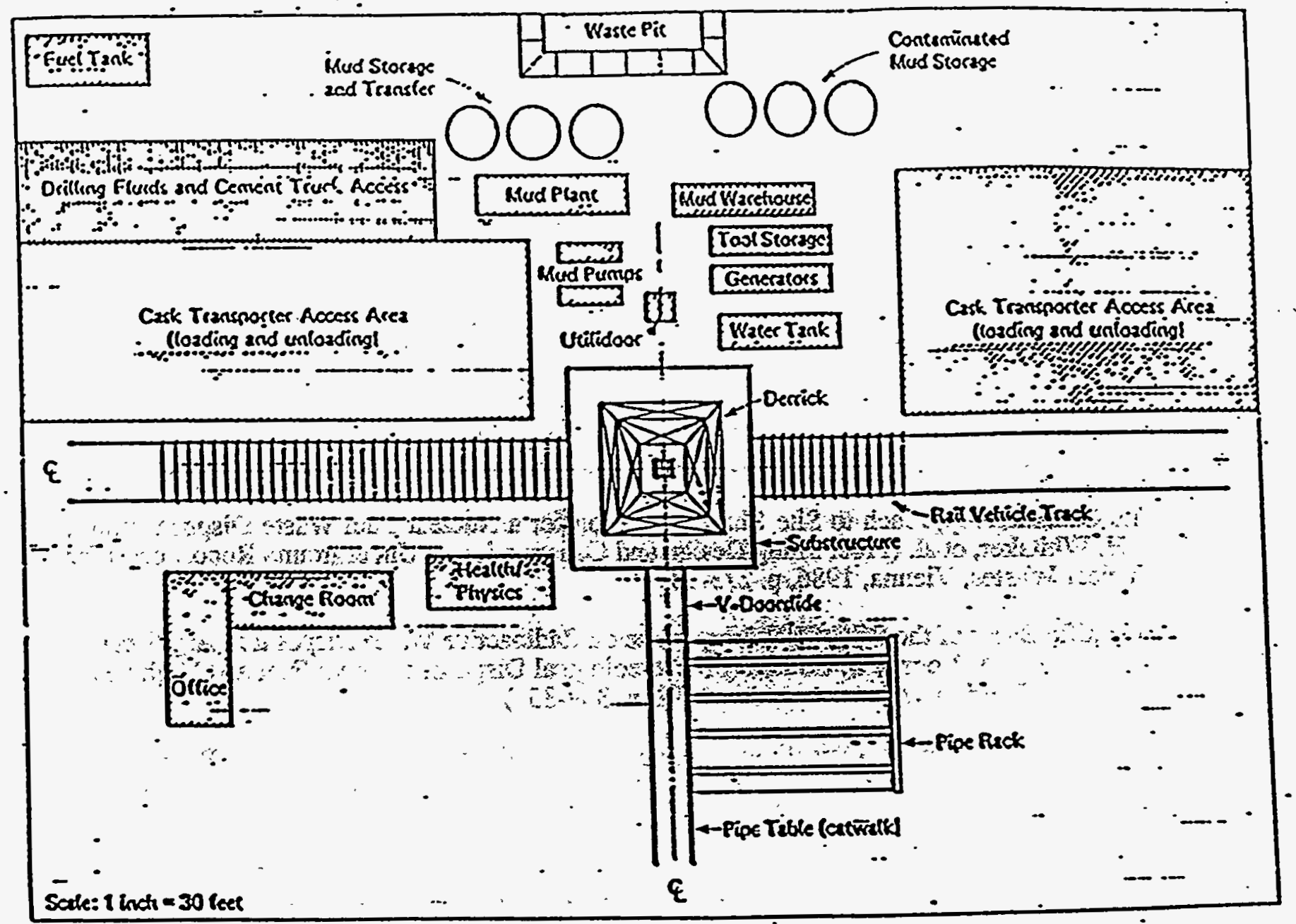

Figure 2

Conceptual Layout of Emplacement Facility (redrawn from Ref. 14) 


\section{References}

1. Management and Disposition of Excess Weapons Plutonium, National Academy of Sciences, National Academy Press, Washington, D.C. 1994.

2. Oil and Gas Journal, 2/17/89.

3. Status of Direct Disposal of Spent Fuel in Germany, K. D. Closs (et al.) (Proc. Geological Disposal of Spent Fuel and High Level and Alpha Bearing Wastes, Antwerp, Oct. 1992, p.273-282).

4. Swedish Development of Concepts for Direct Disposal of Spent Fuel, C. Svemar, (Proc., Geological Disposal of Spent Fuel and High Level and Alpha Bearing Wastes Antwerp, Oct. 1992, p. 239-250).

5. Swedish Spent Fuel Management: Systems, Facilities, and Operating Experiences, J. Vogt, (Proc. 1993 International Conference on Nuclear Waste Management and Environmental Remediation, Prague, p. 87-92).

6. German Program for Vitrified HLW and Spent Fuel Management, W. Lutze (et al.) (Proc, 1993 International Conference on Nuclear Waste Management and Environmental Remediation, Prague, p. 79-86).

7. Geological Disposition of Spent Fuel, High Level and Alpha Bearing Wastes,.Commission of the European Communities, (Symposium Proceedings), Oct. 1993, Antwerp, Belgium.

8. The Canadian Approach to Site Characterization for a Nuclear-Fuel Waste Disposal Vault, S. H. Whitaker, et al. (Proc. Siting:Design and Construction of Underground Repositories for Nuclear Wastes, Vienna, 1986, p.273-282)

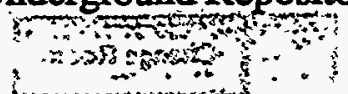

9. Scientific Bases of the SCK/CEN Programme on Radioactive Waste Disposal in Argillaceous Foundations, A. Bonne, G. Collãrd (Proc. Geological Disposal of Spent Fuel añd High Level and Alpha Bearing Wastes, Antwerp; 1992, p. 339-351) .

10. Scientific and Technical Objectives of Underground Laboratories in France, M. Raynal, J. L. Tilson (Proc. International Conference on Nuclear Waste Management and Environmental Restoration, Prague, 1993, p. 505-511)

11. The Aspo Hard Rock Laboratory - A Preparation for the Licensing of the Deep Geological Repository for Spent Fuel in Sweden, G. Backlom (Proc. International Conference on Nuclear Waste Management and Environmental Restoration, Prague, 1993, p. 481-486)

12. Overview of Research Related to Disposal of Long Lived Radioactive Waste Supported by the CEC, K. H. Schaller, et al. (Proc. Geological Disposal of Spent Fuel and High Level and Alpha Bearing Wastes, Antwerp, 1992, p. 405-413).

13. Oil and Gas Journal, 2/18/93.

14. Very Deep Hole Engineering Studies, Woodward-Clyde, ONWI-226, December, 1983. 
15. DECOVALEX: A Multidisciplinary Project in the Field of Thermohydromechanical Processes, F. Kantsky, O. Stephansson, (Proc. Geological Disposal of Spent Fuel and High Level and Alpha Bearing Wastes, Antwerp, 1992, p. 327-335).

16. Scenario Selection Procedures in the Framework of the CEC EVEREST Project, P. Raumbault et al. (Proc. Geological Disposal of Spent Fuel and High Level and Alpha Bearing Wastes, Antwerp, 1992, p.285-296.)

17. The Long-Term Nuclear Explosives Predicament, Final Disposition of Militarily Usable Fissile Material in Nuclear Waste from Nuclear Power and the Elimination of Nuclear Weapons, Johann Swahn, Chalmers University of Technology, Goteberg, Sweden, 1992. 
K. L. Ferguson: "Excess Plutonium Disposition: The Deep Borehole Option (U)"; dated August 9, 1994, (WSRC-TR-94-0266)

\section{Distribution List:}

DOE:

D. N. Bridges, 703-42A

W. D. Clark, 703-F

N. S. Khalil, 703-42A

S. M. King, 703-A

\section{WSRC:}

J. G. Angelos, 773-41A

J. S. Allender, 773-41A

C. E. Apperson, Jr., 773-24A

M. W. Barlow, 730-B

R. W. Benjamin, 773-41A

F. Beranek, 773-A

F. F. Cadek, 730-B

S. S. Cathey, 719-4A

E. R. Conatser, 773-41A

J. D. Cohen, 773-A

J. P. Duane, 704-F

M. E. Dupont, 773-41A

T. H. Gould, 773-41A

M. J. Hitchler, 992-1A

N. C. Iyer, 773-A, D1123

C. B. Jones, 730-B

J. F. Krupa, 773-41A

M. R. Louthan, Jr., 773-A, D1138

R. E. Meadors, 773-41A

E. N. Moore, 773-41A

W. R. McDonell, 773-41A

J. M. McKibben, 773-41A

P. B. Parks, 773-41A

L. M. Papouchado, 773-A

T. S. Rudisill, 773-A

S. R. Salaymeh, 992W-1

L. A. Salomone, 992-4W

C. B. Shedrow, 773-42A

R. A. Smith, 773-41A

I. K. Sullivan, 773-41A

M. F. Sujka, 703-A

B. K. Taylor, 773-41A

S. V. Topp, 773-41A

G. G. Wicks, 773-A 